\title{
People's Understanding of the Off-Court Talak (Case Study in Nagari Koto Tuo, IV Nagari District, the Sijunjung Regency)
}

\author{
Merlin Putri ${ }^{1}$, Shafra ${ }^{2}$ \\ Institut Agama Islam Negeri Bukittinggi \\ Email: merlinputri.tkn@gmail.com¹, shafraelhaqqi@gmail.com²
}

\begin{abstract}
This study describes the understanding of the people of Nagari Koto Tuo, IV Nagari District, The Sijunjung Regency about divorce (talak) outside the Religious Court. Ideally, with the enactment of Law No. I of 1974 on marriage, talak should be decided in the Religious Court. However, this ideal procedure does not apply effectively in Nagari Kuto Tuo. Although the local settlement is not distant to the local Religious Court and the access for transportation is easy, many husbands recklessly decide to divorce their wives at home during the dispute between them without registering their lawsuits to the court. The purpose of this study is to lower the off-court divorce rate and raise legal awareness of the public about the importance of following the prevailing regulation regarding divorce in Indonesia. This is important because divorces decided without statutory procedures have adverse impacts, especially for women and children. This study uses a qualitative approach, with the divorced wives being the subject of the study. The data collection techniques include observation, interviews and documentation. Data validity techniques follow the triangulation method, whereas data analysis is performed through the following steps: data collection, data reduction, data presentation and conclusion drawing. This study found that the understanding of the people in Nagari Koto Tou about divorce is shaped by classical Islamic jurisprudence (figh) that posits husband to have the absolute right to divorce. With this absolute right, husbands can decide to divorce their wives whenever and wherever they want without being bothered to consider registering it formally to the local Religious Court. The divorced wives are left in despair without any power to defend her right. This provision on divorce is considered indisputable let alone contested. As a consequence, this off-court divorce generally leaves women traumatized, making many of them unwilling to get another marriage. This trauma partly contributes to the number of off-court marriages, for they do not see its importance. Legal certainty obtained from the
\end{abstract}


court's verdict of divorce as recorded by the divorce certificate is deemed unnecessary, for they would not remarry in the future.

Keywords: understanding, society, divorce, religious court.

\begin{abstract}
Abstrak
Kajian tulisan ini adalah mendeskripsikan pemahaman masyarakat Nagari Koto Tuo Kec. IV Nagari Kab. Sijunjung tentang penjatuhan talak tidak di Pengadilan Agama. Idealnya, dengan telah berlakunya UU NO. I tahun 1974 tentang perkawinan, aturan bahwa talak mesti di Pengadilan Agama, sudah tegak dan berjalan. Namun prosedur penjatuhan talak itu, tidak berlaku secara efektif. Padahal dilihat dari segi jarak, jarak tempuh dari rumah masyarkat ke Pengadilan Agama setempat tidak jauh, dan transportasinya mudah. Akan tetapi faktanya, masih banyak suami yang menjatuhkan talak tidak mengajukannya ke Pengadilan Agama setempat. Para suami itu menjatuhkan talaknya di rumah, saat terjadinya pertengkaran suami isteri yang terjadi diantara mereka. Tujuan kajian ini adalah menurunkan angka perceraian di luar prosedur serta menumbuhkan kesadaran hukum kepada masyarakat tentang pentingnya perceraian itu dilakukan sesuai prosedur hukum, karena penjatuhan talak yang dilakukan tanpa prosedur perundang-undangan berdampak buruk. Terutama sangat dirasakan oleh perempuan yang ditalak dan anak-anaknya. Dari kajian yang dilakukan, ditemukan bahwa pemahaman masyarakat terkesan fikih klasik. Masyarakat Nagari Koto Tou Kec. IV Nagari Kab. Sijunjung memahami bahwa suami memiliki hak mutlak atas talak yang dimiliknya. Hak mutlak itu, menjadikan suami dapat menjatuhkan talaknya kepada isteri tanpa perlu melakukan pengajuan ke Pengadilan Agama setempat. Suami dapat mejatuhkan talak kepada isterinya kapan pun ia mau dan dimana pun. Isteri yang dicerai terpaksa menerima penjatuhan talak dari suaminya tersebut, walaupun dirinya tidak rela. Aturan fikih tentang hak mutlak suami terhadap talak itu tidak bisa dibantah apalagi diganggu gugat. Perceraian ini umumnya menyisakan trauma kepada perempuan yang dicerai bahwa dirinya tidak akan menikah lagi, sehingga tidak penting juga mengurus perceraiannya ke Pengadilan Agama. Kepastian status yang didapatkan dari akta cerai yang dikeluarkan oleh Pengadilan agama dirasa tidak membawa manfaat bagi perempuan. Hanya segelintir yang memahami pentingnya penjatuhan talak ke
\end{abstract}


Pengadilan Agama untuk tegaknya kepastian hukum, khususnya untuk isteri dan anak.

Kata Kunci: Pemahaman, Masyarakat, Talak, dan Pengadilan Agama

\section{INTRODUCTION}

Every married couple dream of happy marriage life. Nevertheless, disharmony is sometimes inevitable. The differences and arguments that colour marriage not rarely ends up with divorce. One form of divorce is talak (Ghazaly, 2010, p. 191) Talak (henceforth: divorce) is the removal or breaking of the bonds of marriage between husband and wife. From the perspective of Islamic jurisprudence, divorce is halal but loathed by Allah SWT. The loath of Allah of divorce is stated in the following hadith (al-Kahlani, 1995, p. 169)

Meaning: Ibn 'Umar (may Allah have mercy on him) said: "The lawful act that Allah loath is divorce." (H.R Abu Dawūd and Ibn Mājjah).

Ibn Umar's hadith on divorce mentioned above implicitly indicates that divorce should only be the final solution among other measures in cases of recurring disharmony between the husband and the wife that can hardly be

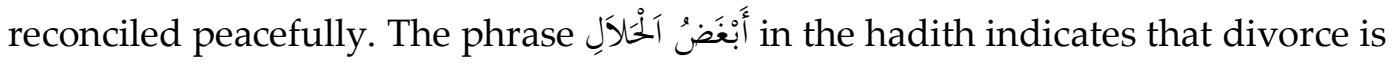
a thing that God hates very much. Therefore, divorce is only permissible when there is no other way to maintain a marriage for married couples.

Fiqh literature describes divorce as the husband's prerogative to his wife. The husband can decide to divorce his wife without any other parties or institutions can intervene. Accordingly, there is no restriction whatsoever for a husband to divorce his wife anywhere and anytime. His declaration of divorce towards his wife does not require the presence of other parties, including the religious court, for divorce is only the right of the husband. The concept of husband's absolute divorce is what society understands. This is how divorce understood as regulated by Islam and should be obeyed by its adherents.

Unlike those fiqh literature, in Indonesia divorce is regulated in statutory procedures. Divorce, in fact, is one of the state's concerns. Divorce is stipulated in Law No. 1 of 1974 on Marriage. This Law is equipped with Government Regulation No. 9 of 1975 concerning Statement of Practice of Law No. 1 of 1974. This legislation is general and applies to all Indonesians. While specific to Muslims, there is another regulation, namely Law no. 7 of 1989 on Religious 
Court. This law is then equipped with The Compilation of Islamic Law (Kompilasi Hukum Islam, KHI) Presidential Instruction Number I year 1991.

In general, there are several divorce procedures listed in Article 39 of Law No. 1 of 1974 on Marriage, namely (Undang-undang Republik Indonesia Nomor 1 Tahun 1974 Tentang Perkawinan Dan Kompilasi Hukum Islam, 2013, p. 3) : 1) Divorce can only be done before the Court of Session after the Court in question seeks and unsuccessfully reconciles the two parties; 2) To make a divorce there must be enough reason, that husband and wife will not be able to live together as a husband and wife. 3) The procedure of divorce before the Court session is stipulated in its own laws and regulations.

As for the Compilation of Islamic Law (KHI), divorce is stipulated in Article 113, Article 114, and Article 115. Regarding divorce, Article 114 of the Compilation of Islamic Law (KHI) mentions that divorce is a husband's pledge before the religious court hearing which is one of the reasons for the breakup of a marriage in the manner referred to in Article 129, Article 130, and Article 131. Article 115 of the Compilation of Islamic Law (KHI) and Law No. 7 of 1989 concerning Religious Courts also explains that divorce can only be done in front of a religious court session after the Religious Court tries and does not succeed in reconciling the two parties.

All of those laws and regulations prove that divorce specifically for Muslims have been arranged accordingly by the state so that married couples would not break for a reckless divorce declaration. Any married couple who wants to decide on divorce must register a lawsuit in court, and only after mediation in court is unsuccessful can the divorce be decided.

Although the Law has governed the issue of divorce in Indonesia, many people continue to disregards the prevailing regulations, including the people of Nagari Koto Tuo, IV Nagari District, the Sijunjung Regency. In this village, the reckless divorce declared at home is prevalent. It is more significant that Law No. 1 of 1974 on Marriage has been generally enacted for 45 years. Thus, it is ironic as well as alarming that in reality the regulations on divorce are not fully understood by the people, especially the people of Nagari Koto Tuo.

When viewed from the geographical perspective, the location Religious Court is not distant from the local settlements of Nagari Koto Tuo. Sijunjung Religious Court is located at M. Yamin street No. 65 Muaro, Sijunjung District, Sijunjung, which can be reached in approximately ten minutes from Nagari Koto 
Tuo. Thus, access is not a factor that inhibits divorce registration to the court, because every house in Nagari Koto Tuo has at least one means of transportation to use.

In addition, the local Religious Court in cooperation with the Local Government has conducted annual counselling related to marriage to the people of all districts in the Sijunjung Regency. With this effort, the public should have had enough insight into the divorce procedure. Nevertheless, it is quite surprising that the people remain unwilling to register their divorce through the statutory procedures as legislated by the state.

In addition, the Supreme Court (Mahkamah Agung, MA) has issued a Supreme Court Regulation (Peraturan Mahkamah Agung, Perma) No. 1 the year 2014 on Guidelines for The Provision of Legal Services for The Poor, that ensures that the people struggling economically would get prodeo (free of charge) legal service. For this reason, financial issues should not also be a problem for the husband in Nagari Koto Tuo to refrain from registering their divorce to the Religious Court, for the State guarantees the necessary financial cover for it.

Accordingly, it is understood that what is meant by off-court divorce in this study is divorce (talak) that the husband declares towards his wife without involving the local religious court. In other words, divorce outside the court is a husband divorcing his wife at home, not through the Religious Court. The statistic between 2016-2019 records off-court divorce cases in Nagari Koto Tuo, as in the following table: (Putra, 2019)

\begin{tabular}{|c|c|c|c|c|c|}
\hline \multirow{2}{*}{ No } & \multirow{2}{*}{ Name of the Jorong } & \multicolumn{4}{|c|}{ Year } \\
\hline & & 2016 & 2017 & 2018 & 2019 \\
\hline 1. & Jorong Rantau Jambu & 2 & 1 & 3 & 4 \\
\hline 2. & Jorong Koto Tangah & 0 & 0 & 1 & 3 \\
\hline 3. & Jorong Bukik Malintang & 1 & 2 & 2 & 3 \\
\hline & sum & 3 & 3 & 6 & 10 \\
\hline
\end{tabular}

The table shows that the number of off-court divorce cases between the people of Nagari Koto Tuo increases from year to year. In 2016, there were three cases, in 2017 there were as many as three cases, 2018 records six cases, and eventually, in 2019 there were ten cases. 


\section{Fitrah \\ T Jurnal Kajian Ilmu-ilmu Keislaman}

Vol. 7 No. 1 June 2021

Against this backdrop, the increased number of cases of divorce taking place outside the Religious Court needs further study. What is the background of off-court divorce cases between the people in Nagari Koto Tuo? How is the understanding of the people of Nagari Koto Tuo about divorce outside the Religious Court?

\section{RESEARCH METHOD}

This study follows the qualitative research method, which Bogdan and Taylor, in Moleong (2007:4). This research was conducted in Nagari Koto Tuo, IV Nagari District, the Sijunjung Regency. This study uses primary and secondary data sources, which, based on Lofland and Lofland explanations, take shape as words and actions. In addition to that, this study also looks at additional data such as documents and others(Moleong, 2007, p. 157). The data sources in this study are obtained from, first, the subjects of research, namely individuals or groups of individuals who are at the centre of attention or the target of research (Arikunto, 2006, p. 145). They are the primary data sources. The subjects of this research include the couples who had their divorce outside the court, not through hearings in the Religious Court. The selection of research subjects is conducted randomly and based on the adequacy of data. In the search phase of the research subjects, researchers got ten couples that had their divorce not through the Religious Court. However, there is a specific difficulty to meet exhusbands, because they no longer live in Nagari Koto Tuo. The second source is informants, that are, the persons who provide the information. With this definition, informants can be also called respondents, if the information is obtained through the request by researchers. A respondent is a person who is asked to give information about a fact or opinion. Informants are widely used in qualitative research (Arikunto, 2006, p. 145). Informants are used as primary data sources. The informants referred to in this study are the certain individuals interviewed by the researchers (Bagong and Sutinah, 2006, p. 172). The third data source of this study is informants who come from local communities such as families, neighbours, village leadership/officials who know or recognize the research subjects. The fourth source is written documents. The written sourcesplaying as a supportive element-of this research includes archives or documents about monographic data of Nagari Koto Tuo, namely the geographical condition, the population data, the religious data of residents in 
Nagari Koto Tuo and data on economic conditions of the people in the village. Including this kind of source are books and articles that are relevant in helping with research problem-solving.

There are several methods of data collection in this study, namely observations and in-depth interviews. In this study, interviews were conducted in a flexible, informal, intimate and relaxed setting. Interviews were conducted on an ongoing basis. To obtain a fixed validity, researchers use data triangulation techniques, that are data validity techniques using external materials for comparison (Moleong, 2007, p. 330). The method used in this approach is descriptive-analytical that is used to describe the issue of the off-court divorce. The analytical steps are as follows: 1) Data collection: Researchers record objectively and as they are following the results of observations and interviews in the field. Data collection in this study was conducted through observations, interviews, and documentation on written data sources; 2) Data reduction: Data reduction is conducted upon the results of interviews with research subjects (divorced wives) from informants who are not tied to the focus of research and upon the main focus of the interview from the improvisation organically growing during the interview. After the selection is made, the description is formulated, and eventually ends with drawing the conclusion; 3) Data presentation: The data that has been reduced or classified in the previous phase is then presented in the form of text or narrative description based on the possible systematics, in order to be drawn from it the conclusions following the problems presented in the study; 4) Drawing conclusions / verification: From the data that has been compiled, then researchers conclude the phenomenon of off-court divorce in Nagari Koto Tuo.

\section{RESEARCH FINDINGS AND DISCUSSION}

\section{Divorce in Islamic Classical Jurisprudence (fiqh) and Its Procedures}

Talak is an Arabic word that is "إِطْلَقَ" talāq means to release or leave (Sabiq, 1982, p. 7). The term refers to the breaking of a marriage bond and the end of a marital relationship. Lexically, talāq means to release and to set something free. (Tihami and Sahrani, 2010, p. 229). Talak as a terminology is associated with the breakup of the marriage, because with it between husband and wife have been separated, or each of the two is free from another. From the terminological point of view, the majority of jurists do not 
differ much in formulating the definition of talāq. It is to relinquish the marriage bond with divorce's expression or the likes or to untie the marriage in an instant effect (divorce ba'in) or the future (after the end of 'iddah talak raj'i) with a specific expression (Syarifuddin, 2011, p. 198).

In the formulations presented by the jurists in figh literature, three keywords indicate the nature of divorce. First: the word "let go" or "open or leave" means that the divorce is releasing something that has been bound, namely the bonds of marriage. Second: the word "marital bond" means that the divorce ends the marriage relationship that a couple had had. If marriage allows sexual encounters between husbands and wives, divorce makes it harām (forbidden). Third: the phrase "with divorce's expression or the likes" means that the breakup of marriage should be effective through a declaration or a statement. The declaration in this context is the specific declaration affecting divorce. It is not talāq if the breakup of marriage does not go through a declaration, such as for the death of one of the spouses. Because talāq removes the bonds of marriage, then after the loss of the marriage bond the wife is no longer has any legal binding to her husband.

In principle, the origin legal status of talāq is makruh(Tihami and Sahrani, 2010, p. 249) hadith of the Prophet SAW, as follows:

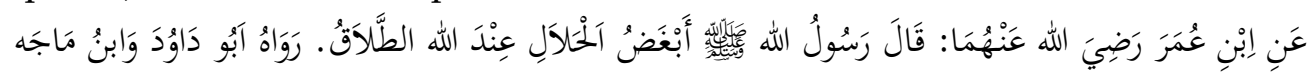
Meaning:Ibn 'Umar (may Allah have mercy on him) said: "The lawful act that Allah loath is divorce." (H.R Abu Dawūd and Ibn Mājjah). (r Al- Asqalani, 2013, p. 495)

According to this hadith, divorce is hated as long as it does not base on sufficient reason for it, even if divorce is lawful. It is because it corrupts marital relationships that contain the goodness suggested by religion. Therefore, such kind of divorce is hated (Sayyid Sabiq).

This hadīth also shows that divorce should be the last solution in overcoming household problems. For this reason, Islamic jurisprudence restricts husbands from using their divorce rights up to three times. If divorce declared once or twice, the husband and the wife have the opportunity to reunite. This rule is stated in Q.S Al-Baqarah verse 229.

But if the divorce is declared the third time already, then the door of togetherness is closed to both. The opportunity for the husband and the wife to 
reunite would only be re-opened after the ex-wife has married another man. This is stated in Q.S al-Baqarah verse 230.

Al-Baqarah verse 229 explains the gradual procedure of divorce. The husband should declare his divorce statements one after another. Furthermore, the divorce procedure is stipulated in Q.S At-Talāq verse 1 as follows:

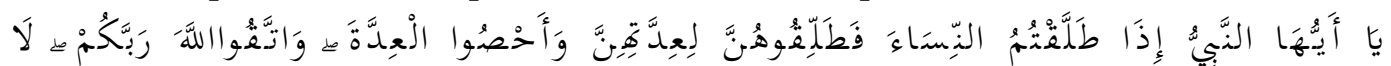

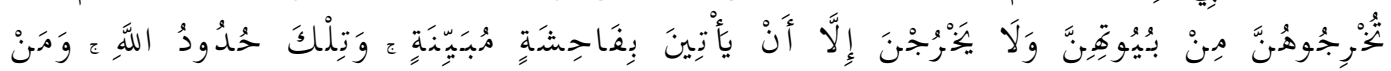

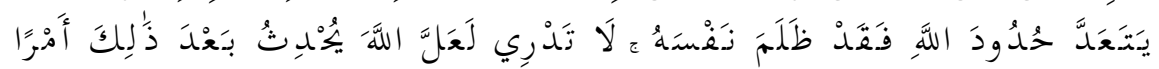

Meaning: "Prophet, when any of you intend to divorce woman, do so at a time when their prescribed waiting period can properly start, and calculate the period carefully: be mindful of God, your Lord. Do not drive them out of their homes-nor should they themselves leave-unless they commit a flagrant indecency. These are the limit set by God-whoever oversteps God's limits wrongs his own soul-for you cannot know what new situation God may perhaps bring about."

This verse explains that ideally divorce should be conducted in a situation in which the wife can proceed to her 'iddah immediately. The wife can proceed to her 'iddah immediately if she is not on her period during which she has not had sexual intercourse with him.

In Q.S. At-Talāq verse 2, Allah explains that in the time of iddah, the husband has the opportunity to reunite (al-rujū ) with his wife in a right manner. Even if a divorce should happen, it should be in the right manner as wall. That is the general description of the divorce procedure. No further explanation found in the classical jurisprudence concerning the divorce proceedings before the Court of Religion.

\section{Divorce in The Laws and Regulations in Indonesia}

In Indonesia, there are two kinds of divorce: cerai talak (lit. talak divorce) and cerai gugat (lit. sued divorce). The former is when a divorce is initiated by the husband, whereas the latter when it is initiated by the wife. The word cerai in The Dictionary of Indonesian Language means: 1) separation, 2) break up as husband and wife. While the word perceraian means: 1) separation, 2) [issues] about divorce (between husband and wife) (Tim Penyusun Kamus Pusat Pembinaan Dan Pengembangan Bahasa, 1997, p. 185). Juridical divorce means the breakup of marriage which results in the breakup of the relationship as a husband and wife. 
In general, the breakup of a husband and wife can be caused by death, divorce, and a court decision. This is stated in Law No. 1 of 1974 on Marriage in Chapter VIII on the breakup of the marriage and its consequences, as described in Article 38, as the following: "Marriage may break up due to: (a) Death, (b) Divorce, and (c) Upon Court Decision".

Furthermore, Article 39 stipulates: 1) Divorce can only be done before the Court of Session after the Court in question seeks and unsuccessfully reconciles the two parties; 2) To make a divorce there must be enough reason, that husband and wife will not be able to live together as a husband and wife; 3) The procedure of divorce before the Court session is stipulated in its own laws and regulations.

Paragraph 2 article 39 of Law No.1 of 1974 concerning Marriage does not justify divorce by way of agreement between husband and wife without a valid reason. This is also what is strongly indicated by ibn Umar's hadith as mentioned, which explains that divorce is something that God hates very much. Accordingly, Law No. 1 the year 1974 on Marriage is in accordance with the guidance of the hadith. Based on both the hadith and the law, following the statutory procedures of divorce is mandatory; the sole agreement between the husband and the wife for a divorce is not sufficient.

This study limits its concern on talak divorce. On this kind of divorce, the Compilation of Islamic Law (KHI) in article 17 specifically defines talak as follows: "divorce is the husband's pledge before the court of religion which is one of the reasons for the breakup of marriage" (Syaifuddin, 2013, p. 18).

It is clear that talak divorce is a kind of divorce filed into the Religious Court on the initiative of the husband, which is considered valid with all its legal consequences from the moment the divorce is declared (pledged) before the court's session (Article 14 to Article 18 PP No. 9 the Year 1975 on Implementing Instructions and Law No. 1 the Year 1974 on Marriage).(Syaifuddin, 2013, p. 37)

Talak in the legislation of marriage in Indonesia is recognized as the right of the husband. Nevertheless, to prove that divorce is the final solution in marriage, the husband must submit his divorce to the Court of Religion. This is so so that the husband does not arbitrarily declare divorce towards his wife. Also, it is with the intention to minimize divorce cases. The state in this case intervenes in the divorce right of the husband by taking the Court of Religion into account. 
In Article $129 \mathrm{KHI}$, the procedure for filing divorce to the Court of Religion is stipulated, as follows:

"A husband who will declare talak upon his wife submits an application both oral and written to the Religious Court of his wife's residence accompanied with the reasons and asks that a hearing be held for that purpose".

In line with article 129 KHI, Government Regulation No. 9 of 1975 also explains the procedure for filing for divorce in Chapter V Article 14, which reads: "A husband who had married according to Islamic law that intends to divorce his wife files a letter to the court of his residence which contains a notice that he intends to divorce his wife accompanied by his reasons for it and asks the Court to hold a hearing for that purpose."

The procedure for submitting divorce to the Court of Religion must be done by the husband if he divorces his wife. If the husband divorces his wife without the procedures stipulated by law, there would be adverse impacts on the wife and children. Divorce without legal procedure would also result in the disorganization of marriage. Therefore, it is necessary for any spouse intending for a divorce to submit their affair legally to the Religious Court.

\section{The Phenomenon of the Off-Court Divorce in Nagari Koto Tuo}

\section{The History of Nagari Koto Tuo, IV Nagari District, the Sijunjung Regency}

The name Nagari Koto Tuo comes from the word "Koto Nan Tuo" (lit. a city which is old). According to the prevalent oral history and local historiography (tambo) the current Koto Tuo and its nearby village, Nagari Palangki, was previously named Nan Ampek Koto (lit. the four cities), namely:

1. Boduok : Ruled by Haji Nan Kiramaik with Dt. Rajo Mudo as Pangulu. Their positions in Kerapatan nan Limo Koto were as tiang panjang (lit. a long pole) coming from Padang Ganting.

2. Muaro Hall : Ruled by Dt. Lelo Panjang with Dt. Pangulu Basa as Pangulu. Their positions in Kerapatan nan Limo Koto as a Sandi Padek originated from Andaleh through Payakumbuh.

3. Mangunyik : Ruled by Dt. Sinaro Nan Putiah with Dt. Rajo Stone Palembang as Pangulu, Their positions in Kerapatan nan Limo Koto as Parik Paga from Tanah Datar (Limo Kaum). 
4. Comintato : Ruled by Dt. Mogek Kanamaan with Dt. Pangulu Sutan as Pangulu whose positions in Kerapatan nan Limo Koto as Camin Taruih, originated from Padang Ganting.

Along with the existence of Nan Ampek Koto people, the surrounding areas such as Guguak Gadang, Limau Sundai, Batu Kondiek (the areas of Koto Tuo that border with Sinjunjung district) already had inhabitants. During the dry season, they had water difficulties. They went to Batang Palangki River to fetch water. Then gradually they moved to the area around the river bank. The riverside area became Koto Tuo now.

In the XIV century AD came the Ponggang people from Padang Buluh Kasok (padang Sibusuk now), led by Ninik Romai along with with three Datuak, namely:

1. Dt. Sampono Bumi, Caniago Tribe.

2. Dt. Lenggang Sampono, Dalimo tribe.

3. Dt. Paduko Rajo, Suku Mandahiling.

This group stopped in Silambau (Batu Putiah). It is reported that in order to relieve his grief, Ninik Romai went across the river to see the surrounding nature-Nagari Palangki now. Eventually, he thought to make it a place to live. Ninik Romai went towards the upstream area of the Air Silambau. He found a white rock, that he then halved into two pieces; one made for perlimauan whereas the other was swept into a mundam.

After noticing the mundam containing sampolah limau, Tuan Haji nan Kiramaik wanted to find the person who possessed the mundam by turning down the stream of Palangki water rod to meet Dt. Lelo Panjang and Dt. Sinaro nan Putiah in Batu Mangunyik (Koto Tuo Now).

After the event of mundam hanyuik, with the deliberations of the three Datuak, the people of Nan Ampek Koto and their nieces agreed that some of them would move and established a village in Palangki, whereas the other remained in Koto Tuo. From this point, Koto Tuo was commonly referred to as "Koto Tingga", or, according to some others, "Kato Nan Tingga". As recorded by the local expression: "Nan poi jo kain pandukuang nan tingga jo kampuo buayan," which means the farside land forest became the possessions of the people who moved away, wheres the rest became the possessions of those who settled in Koto Tuo.

After Ninik Romai settled in Palangki, the people of Nan Ompek Koto and Tujuh Koto met in Bukik Nan Bulek. They agreed to appoint Dt. Baramban Bosi as their leaders, dubbed in local expressions as Indak Rajo Kagonti Rajo. He 
got the epithet Dt. Bagindo Rajo. Furthermore, more leadership structures appointed. Tuanku Nan Kiramaik was appointed with the epithet Datuk Rajo Mudo. Datuk Nan Barompek was founded in Koto Tuo, Datuk Nan Salapan in Palangki and Datuk Nan Batujuah in Muaro Bodi. This completed the establishment of Nagari Koto Tuo, Palangki and Muaro Bodi by custom.

During the Dutch era, Koto Tuo went under the administration of the Sijunjung district. It then moved into district Sawahlunto. After the establishment of the Sawahlunto/Sinjunjung Regency in 1948, in Tanjung Bonai established District IV Nagari, consisting of five Nagari namely Koto Tuo, Palangki, Muaro Bodi, Koto Baru, and Mundam Sakti. In 1949 the leaderships of those Nagari set a meeting, that involved:

1. AB. Dt. Rajo Mudo from Palangki

2. AM. Limbu Batuah from Muaro Bodi

3. Raji'un Malin Mudo from Koto Tuo

4. S.P. Rajo Batuah from Koto Baru

5. H.A. Martamin from Mundam Sakti

This meeting resulted in an agreement to establish a district that was initially named District Sembilan Koto at the downstream side but was then renamed into District V Nagari. Furthermore, the name of District V Nagari was changed to IV Nagari, without the process of deliberation with the local leadership. During this time, the size of the Nagari was identical to that of it during the Dutch colonial time. However, Koto Tuo continued to implement an autonomous self-governance system headed by a Wali Nagari.

After the PRRI uprising, Nagari Consultative Assembly (Badan Musyawarah Nagari, BMN) was formed and appointed Lengah Rangkayo Mulie from Koto Tuo as Wali Nagari of Palangki. Furthermore, BMN transformed into DPRN (Nagari People's Representative Assembly) and later became Kerapatan Nagari.

Since the enactment of Law No. 5 of 1979 on Village Government (Pemerintahan Desa), Koto Tuo transformed into one of the villages in District IV Nagari Sawahlunto/Sijunjung. On October 20, 1982, Koto Tuo represented in the village government pilot from District IV Nagari. In April 1983 all jorong in West Sumatra transformed into desa and the Nagari governance system was abolished.

With the issuance of Law No. 22 of 1999 on Regional Autonomy (OTODA) and Provincial Regulation No. 9 of 2000 on returning to Nagari that is further described in the District Regulation of Sawahlunto / Sijunjung No. 22 of 2001 on Nagari Government, Koto Tuo was designated as one of the Nagari in 
the Sawahlunto / Sijunjung Regency. In Koto Tuo, the BPAN election was held and Wali Nagari was elected on July 4, 2002. Hence, Koto Tuo was officially reconfirmed as a Nagari.

Nagari Koto Tuo belongs to District IV Nagari, the Sijunjung Regency with an area of 806 ha. The distance of the nagari from the capital of the district is only about $5 \mathrm{Km}$, from the capital of the regency is about $7 \mathrm{Km}$, whereas from the provincial capital is about $110 \mathrm{Km}$. Geographically Nagari Koto Tuo is a flat and hilly area located at an altitude of 150-200 MDpl. The average temperature in Nagari Koto Tuo is at 24-34 C with an average rainfall per year of 2,500 Mm. The boundaries of the Nagari Koto Tuo region are as follows:

\begin{tabular}{lll}
\hline Northside & $:$ & Bordered by Nagari Muaro and Nagari Padang Laweh \\
& Selatan \\
\hline Southside & $:$ & Bordered by Nagari Palangki \\
\hline East & $:$ & Bordered by Nagari Palangki, Nagari Kandang Baru, and \\
& Nagari Pamatang Panjang \\
\hline Westside & $:$ & Bordered by Nagari Palangki \\
\hline
\end{tabular}

Nagari Koto Tuo is structured with three jorong, namely Jorong Bukik Malintang, Jorong Koto Tangah, and Jorong Rantau Jambu.

\section{People's Understanding of Off-Court Divorce in Nagari Koto Tuo}

Before explaining the understanding of the people of Nagari Koto Tuo about divorce decisions outside the Religious Court, it is necessary to explain in advance what is meant by the understanding of the people/society. Pemahaman masyarakat (people's understanding) consists of two words, namely understanding (pemahaman) and the people/society (masyarakat). In the Indonesian dictionary, pemahaman comes from the word paham that is conflated with prefix-suffix pe and an. Etymologically, paham means tanggap (perceptive), mengerti benar (truly understand), pandangan (view), and ajaran (teaching) (Partanto, 2000, p. 279) Understanding (pemahaman) is the process of thinking and learning. Thus, understanding is reached through thinking and learning. Understanding is a process, an act and a way to understand. As for the terminological perspective for understanding, it is "the ability of a person to understand something after it is known and memorized (Sudijono, 2010, p. 50)

In other words, understanding is knowing something and being able to see it from many perspectives. Understanding is a cognitive level above recognition and memorization. Another way to define understanding is as a level of cognitive competency that enables people to comprehend the meaning or a 
concept, a situation, and a fact of a matter they know (Purwanto, 2010, p. 44) In this case, the person who understands something does not only memorizes verbally but understands the concept of the problem or the fact in its entirety. Thus, it can be concluded that a person who understands is not who memorises something, but who has the ability to capture meaning more deeply.

Masyarakat, on the other hand, in English is "society". The word comes from a Latin word, "socius" which means fellow/friend. The term masyarakat comes from the Arabic word "syāraka-yusyāriku-musyārakah" which means association, alliance, cooperation, and participation. In Arabic itself, the people are called mujtama'.

According to Ibn manzur in his Lisan al-Arab, society means the core of everything, that is a place where offsprings grow. Society is an assembly of various people. As for musyārakah, it means united, allied, and in cooperation. Thus, it is understood that society is a group of different people but united in a cooperative bond and comply with the rules agreed together. In other words, society is some people united in constant contacts and common interests even though coming from different backgrounds. These people form a group that lives together and helps each other in their relationships or interacts with each other. So society is a form of human grouping that shows the shared activities occurring from interactions among their members, where the needs of members of the group can only be met by interacting with other individuals. Accordingly, when the word "understanding" is juxtaposed with the word "society", it means the ability of the people in understanding particular problems, facts, ideas or implications truly and intelligently.

As the Muslim community, the people of Nagari Koto Tuo live with constant attempts to carry out the teachings of Islam correctly. It is also the case for the divorce affair; the understanding of the people in this region, in general, is formed from the classical Islamic jurisprudence. Generally, the divorcing husbands or the divorced wives understand that divorce is the husband's absolute right. As such, the husband can divorce his wife anywhere and anytime. This understanding is a driving factor behind the tendency to resolve the divorce through familial deliberation, which means, the off-court divorce. It is considered sufficient and effective if the divorced is witnessed by ninik mamak; then the marriage between the husband and wife has broken up.

The people of Nagari Koto Tuo, especially the divorce married spouses, understand divorce as stipulated by the classical jurisprudence literature. These figh literatures explain that divorce (talak) is as follows: 


$$
\text { حل قيد النكاح بالفظ الطلاق ونحوه }
$$

Meaning: the breakup of the marriage contract with divorce expression or the likes.

It is sufficient with the declaration of divorce from the part of the husband, then immediately the divorce is effective. Divorce is the husband's absolute right. Divorce is legally binding if consciously declared by a husband who is sedate and baligh. Once he denounces divorce's expression towards his wife, then it immediately stands; they already got divorced. A husband or a wife does not have to deal with the Court, for according to the classical jurisprudence, divorce does not require written evidence such as the divorce certificate. The married couple would separate only by the divorce expression from the husband. The right of divorce does not require anyone else in the process of its implementation. Such understanding of the concept of divorce is not only perceived by the divorced husbands and wives but also by local public figures such as bundo kanduang and ninik mamak (Besar, 2020) As a respected member of the community, some of ninik mamak, cadiak pandai, and bundo kanduang recognize that divorce should be filed to the court. However, this rule is considered non-binding, for the validity of the fiqh rules is deemed higher than the state's law over Muslims, especially the people of Nagari Koto Tuo. Figh allows unilateral divorce initiative on the part of the husband. Such understanding illustrates that the people of Nagari Koto Tuo consider that the religious jurisprudence has higher authority than the law of the state, because the religious law comes from God and his Messenger, whereas the laws of the state are made by man. This kind of view inhibits the enactment of the divorce law requiring the husbands to file their affair to the Religious Court from being effective between the people of Nagari Koto Tuo, even though the rule has generally been enacted for 46 years in Indonesia. The strong understanding of figh makes the wife powerless. Whether they are willing or not, they are forced to accept the reality of divorce from their husband.

In addition to the strong loyalty upon classical Islamic jurisprudence on divorce that stipulates divorce as the absolute right of the husband, off-court divorce cases between the people of Nagari Koto Tuo is also related to the trauma over the divorce from the part of the wives. This trauma makes them do not want to remarry. Hence, for them, there is no benefit of filing the divorce affair to the court whatsoever. The divorce certificate they would get from the court verdict should their case is handled through the court would not be of any use for them for their intention to not marry any longer in the future. They let the divorce be and surrendered even though they were not willing. Many of these 
divorced couples have not any children as well, for which reason, again, the divorce certificate would not be useful.

Justification by the wife for her husband's divorce is also due to the rejection of the wife for the presence of other women in her family (Ermayulis, 2020) The husband in this case had an extramarital affair with another woman without her knowledge. This had hurt her heart. As a result, upon the divorce, she decided not to remarry, and hence, saw no interest in taking her case into court.

In addition to the above reasons, the illegal divorce in Nagari Koto Tuo was also triggered due to economic conditions. Most of the Nagari Koto Tuo people works as farmers. In fact, not a few husbands that do not have permanent jobs. Hence, the family daily needs would not be covered, and it caused displeasure among the spouses (Riani, 2020) Eventually, the recurring arguments ended up with divorce between the two parties. Arguments are parts of marriage life. Yet, it quite rarely that the married couple can cope with them wisely. Eventually, with heart heated with anger, a husband declared a divorce expression and immediately left his wife at home and has never return. The wife did not try to persuade the husband's family to return. The wife in this case showed selfishness as well, thus leading to no reconciliation.

Sometimes, the off-court divorce is also caused by the family intervention(Yanti and Erawati, 2020) Parents are too meddling in their children's household affairs, leading to an unhealthy relationship between the couple. Eventually, divorce is inevitable.

Another reason for the off-court divorce is that the divorce declared at home is considered practical, quick, easy, and costless. The people of Nagari Koto Tuo think that the divorce conducted through the Religious Court takes a long time(Marleni, 2020) In court, they would undergo several series of trials. It is different from the divorce declared out of court; it is sufficient that the divorce is witnessed by mamak. When encountering a divorce case, Mamak would testify that the couple had really wanted a divorce. Although there would be a call for reconciliation on the part of Ninik Mamak, it rarely effective and would not last very long. The whole procedure of divorce would not take long and would not need many people involved. Additionally, there would not be any cost whatsoever.

This study suggests that those are the factors leading to divorces without legal procedures, namely filing it to the Court of Religion. It is sufficient that the husband declares a divorce expression at home, as justified by their perception of 
talak that is established from classical fiqh. The people feel that this way of divorce is a fixed religious law and hence must be obeyed. They tend not to accept the divorce rules regulated by the state because the rules of the state are considered violating the rules of religion. The public is not fully aware of the importance of legal certainty over a divorce by her husband. While the husband could immediately marry another woman right after the divorce, that is not the case for the wife for the trauma that she would get from the divorce. This trauma leads these divorced wive to consider that administrative benefits from official court verdict on divorce unuseful.

\section{CONCLUSION}

The people of Nagari Koto Tuo are Muslims. As pious Muslims, they commit to implementing Islamic law, including in the matter of divorce. The rules of divorce understood by the people of Nagari Koto Tuo are divorce rules stipulated by classical fiqh literature. These kinds of literature of jurisprudence describe divorce as the absolute right of the husband. The husband, with his absolute right, can divorce his wife whenever he wants. The husband's decision to divorce his wife does not require intervention from others or even the state. That divorce should be filed into a state-created religious court is considered incompatible with the original concept of Islamic jurisprudence. Such understanding of the people of Nagari Koto Tuo seems rigid.

The entrenched understanding of the people of Nagari Koto Tuo about the absolute right of the husband to divorce was motivated by a rigid understanding of the rules of divorce in the classical figh. Additionally, public awareness of the adverse impact of the off-court divorce is minimum at best. The apathetic attitude of the divorced wives contributes as well to the practice of divorce occurring at home, not to mention the trauma they encounter for it. The intervention from the family of the spouses, upon which each of the husband or the wife cannot proportionately position themselves between a set of priorities, partly becomes a pushing factor for the divorce rate. Finally, the economic factor also plays a role in the occurrence of this kind of divorce. 


\section{REFERENCES}

Al- Asqalani, A.-H. I. H. (2013) Bulughul Mahram, terj. Abu Ihsan al-Atsari. Solo: At- Tibyan.

Arikunto, S. (2006) Prosedur Penelitian (Suatu Pendekatan Praktek). Jakarta: Jakarta.

Bagong and Sutinah (2006) Metode Penelitian Sosial Berbagai Alternatif Pendekatan. Jakarta: Prenada Media Group.

Besar, M. P. (2020) 'Wawancara dengan Cadiak Pandai'.

Ermayulis (2020) ‘Wawancara dengan isteri yang dicerai'.

Ghazaly, H. A. R. (2010) Figh Munakahat. Jakarta: Kencana.

al-Kahlani, M. ibn I. (1995) Subul al-salam, Juz III. Bandung: Maktabah dahlan.

Marleni (2020) 'Wawancara dengan Isteri yang dicerai'.

Miles, M. B. (1992) Analisis Data Kualitatif. Jakarta: Universitas Indonesia.

Moleong, L. J. (2007) Metodologi Penelitian Kualitatif. Jakarta: PT Remaja Rosdakarya.

Partanto (2000) Kamus Ilmiah Populer. Surabaya: Arkolo.

Purwanto, M. N. (2010) Prinsip-prinsip dan teknik evaluasi pengajaran. Bandung, Indonesia: Remaja Rosdakarya.

Putra, T. (2019) ‘Wawancara Pribadi’.

Riani, N. S. (2020) ‘Wawancara Pribadi dengan Isteri yang dicerai’.

Sabiq, S. (1982) Fikih Sunnah. Bandung: Al-Ma'arif (8).

Sudijono, A. (2010) Pengantar evaluasi pendidikan. Jakarta: PT RajaGrafindo.

Syaifuddin, M. (2013) Hukum perceraian. Cetakan pertama. Rawamangun, Jakarta: sinar Grafika.

Syarifuddin, A. (2011) Hukum Perkawinan Islam di Indonesia. Jakarta: Kencana.

Tihami, H. M. A. and Sahrani, S. (2010) Fikih munakahat: kajian fikih nikah lengkap. Jakarta: Rajawali Pers. 


\section{Fitrah}

I Jurnal Kajian Ilmu-ilmu Keislaman

Vol. 7 No. 1 June 2021

Tim Penyusun Kamus Pusat Pembinaan Dan Pengembangan Bahasa (1997) Kamus Besar Bahasa Indonesia. Kedua. Jakarta: Balai Pustaka.

Undang-undang Republik Indonesia Nomor 1 Tahun 1974 Tentang Perkawinan Dan Kompilasi Hukum Islam (2013). Bandung: Citra Umbara.

Yanti, E. and Erawati (2020) 'Wawancara Pribadi dengan Isteri yang dicerai'. 